\title{
Pre-surface preparation features when applying wear resistant composite sprayed coatings
}

JÜRI OLT - Institute of Technology, Estonian University of Life Sciences • jyri.olt@emu.

VIACHESLAV V. MAKSAROV - Department of Mechanical Engineering,

Saint-Petersburg Mining University • maks78.54@mail.ru

Victor A. KRASNYY - Department of Mechanical Engineering,

Saint-Petersburg Mining University = vikras1955@yandex.ru

Érkezett: 2017. 11. 14. - Received: 14. 11. 2017. " https://doi.org/10.14382/epitoanyag-jsbcm.2018.7

\begin{abstract}
In this paper we consider the use of composite metal sprayed coatings for the improvement of the abrasion resistance levels in the working surfaces of friction couples. It is noted that pre-surface preparation, which provides the proper surface roughness that improves the adhesion of the coating to the base, is an important processing step prior to applying such coatings. As a method which enhances the adhesion strength of the sprayed coating, we consider the jet-abrasive (shotblasting) treatment to be ideal. The object of our research was the compression piston rings the internal combustion engine with a composite steel-molybdenum coating. Such coatings provide high abrasion resistance for the rings of a good many large-sized engines. The research that has been carried out allowed the conclusion to be reached that the surface roughness depends on abrasive blasting modes, and that it impacts upon the strength of adhesion between the coating and the base. We proposed the jet-abrasive processing modes, which provide the required roughness to the working surface of the piston ring before spraying.

Keywords: composite coatings, wear resistant sprayed coating, surface roughness, adhesive strength, abrasive jet machining, piston rings.

Kulcsszavak: kompozit bevontok, kopásálló szórt bevonat, felületi érdesség, tapadószilárdság, abrazív vízsugaras megmunkálás, dugattyúgyưrú.
\end{abstract}

\section{Introduction}

Improving the reliability of modern machinery, reducing maintenance costs, ensuring competitiveness, extending useful life, and also carrying out machinery refurbishment by restoring units to like-new operating condition with the help of state-of-the-art technology are the priority trends in technology development.

The utilisation of protective and wear-resistant-coating application technologies, of which gas-thermal and plasma flame processes are preferred choices, is one of the radical methods available when it comes to solving this problem. Current coating equipment, materials, and technologies permit us to significantly reduce or exclude the effect of such factors as erosion, corrosion (including hot corrosion), cavitation, etc on the wear and tear of parts [1].

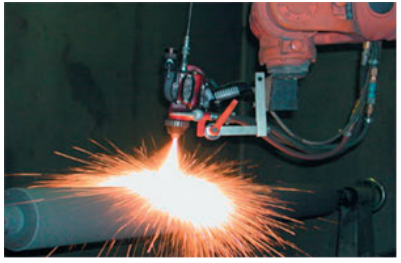

a)

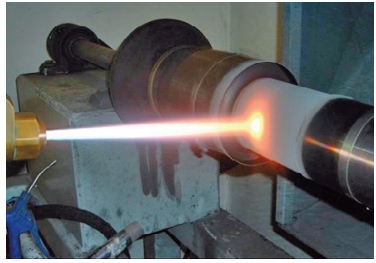

b)
Fig. 1. Gas-thermal (a) and plasma (b) spraying

1. ábra Gázlángos (a) és plazma (b) szórás

Gas-thermal and plasma flame composite coatings (Figs. 1. $a$ and $1 . b$ ) are used for equipment repair and hardening the working faces of new parts. Depending on the purpose of a
Jüri OLT, DSc.

Professor at Estonian University of Life Sciences. His main research areas are fundamentals of production enginering, materials cutting and design of technological machinery.

Viacheslav V. MAKSAROV, DSc. Professor at Saint-Petersburg Mining University, Head of Department of Mechanical Engineering since 2012 and Dean of Electromechanical Faculty since 2015. Spezializes in the field of dynamics of machining technological systems.

Victor A. KRASNYY, PhD. Associate professor at Saint-Petersburg Mining University. Specializes in the field of technological methods of increasing wear resistance of machinery parts. coating and its operating conditions, the requirements can change for strict adherence to the principal parameters of a coating (ie. in terms of its composition, thickness, density, and adhesion) [2,3].

Gas-thermal coatings are used extensively in the manufacture and repair of a number of essential combustion engine components, primarily in terms of cylinder-piston group parts (pistons and piston rings), crankshaft main and rod journals, and a number of other parts.

Abrasive jet machining of the base surface is used extensively as a preparatory operation before applying the spray coating. Such preparation work cleans the surface and upsets its thermodynamic equilibrium with the environment, breaking the chemical bonds of the base surface atoms: i.e. it is activated chemically. However, base surface activity reduces rapidly due to the chemical absorption of gases from the atmosphere and also thanks to oxidation. Besides this, machining roughens the surface, causing a temperature increase in the contact surfaces of deposited particles and roughness peaks, and serving to increase the total area of the applicable welded surfaces. A rough surface has a larger area than a smooth one; this fact also contributes to increasing adhesion strength. Another factor which helps to determine the adhesion efficiency of roughness in the target surface is the volume of roughness cavities which ensures the necessary value of deposited layer shrinkage during cooling $[2,4]$.

The objective of this work is to study the relationship between the adhesion strength of the piston rings' gas-thermal wear- 
resistant composite coating on the working surface's roughness following abrasive jet machining which, in turn, depends upon its prevailing conditions (the distance between the working surface and the nozzle exit, the number of passes, the operating air pressure, and the shot changing frequency).

In industrially advanced countries, the replacement of 'dirty' electrodepositing gas-thermal spraying is viewed as a solution to environmental problems. Many Russian and foreign authors propose various methods of applying protective and wearresistant coatings, including the development and improvement of methods which involve spraying on various vital parts. The thermal spraying process diagram is shown in Fig. 2.

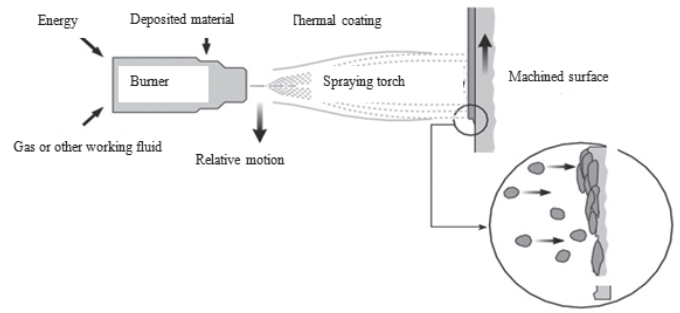

Fig. 2. Schematic diagram gas-thermal coating deposition

2. ábra Gázlángos szórás sémája

The process of applying coatings includes the following operations: preliminary preparation of the target surface in order to obtaining the firm adhesion of the material to be deposited; material preparation; coating application; and machining the coating after its application $[1,2]$.

When coatings more than $1.0 \mathrm{~mm}$ thick are deposited on load-bearing parts, special machining is also used. Such machining can be grouped into types as follows: knurling, notching, grooving, and 'ragged' thread cutting. Threads and grooves should not be deep. Excessive depth leads to excessive porosity and the blistering of fused coatings.

The target surface must be roughened in order to improve coating adhesion. Abrasive jet machining, etching, and electrosparking methods are all used for that purpose. Depositing an intermediate layer which consists of materials which have good levels of adhesion to the base metal is a method that has been used increasingly in recent years.

Abrasive jet machining is the most versatile method. Its advantages are connected with the capabilities involved even in the machining of large areas and oxide film removal from the target surface. Roughness levels depend upon the abrasive type, air pressure, the equipment used, and the surface hardness.

Primary machining of base surface is an important factor in ensuring firm adhesion of the deposited coating to the target surface, because in most cases the deposited coating has bonded with the base surface as a result of mechanical adhesion. Therefore the base surface must be rough enough so that the deposited particles that strike the base surface and are distorted are be bound rigidly to the surface asperities.

The increase in terms of mechanical adhesion strength is connected with the increase of the base surface area and making the base surface more active. This is also important for other types of adhesion. Therefore the intense roughening of the base surface is an important requirement.
Another method of machining the surface before applying the coating is shot blasting.

Shot blasting roughens the target surface. Fig. 3 shows surfaces after shot blasting (a) and after applying the coating (b).

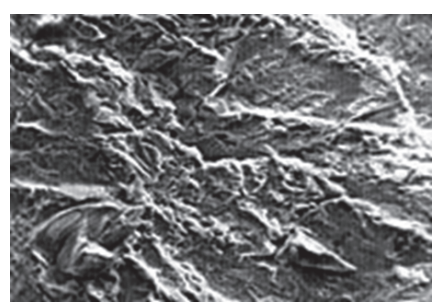

a)

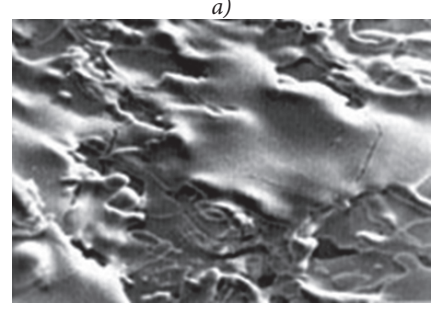

b)

Fig. 3. The surface after shot peening (a) and after deposition (b)

3. ábra Előkészitett felület felületdurvitást követően (a) és bevonat felhordást követöen (b)

\section{Piston ring surface machining for applying a wear-} resistant coating

Operational experience regarding combustion engines demonstrates that their reliability depends to a large extent on the wear rate of the top piston rings as determined by their vibration and stress-strain behaviour, as well as on the composition and technology of the application of a wearresistant coating which permits their structural composition to be controlled.

Coatings are deposited onto the working surfaces of piston rings in order to improve their terminological behaviour. This is an area in which improving wear resistance and ensuring lubrication and sealing under extreme operating conditions are to the foreground. The composite coating material must match the materials used in the construction of the piston ring and the cylinder wall, and also the engine oil. Coating the working surfaces of the piston rings has become widely used. Piston rings in mass produced engines are often coated with chrome, molybdenum, and ferric oxide.

One of the principal reliability factors is the limit to the service life which depends upon the wear resistance of friction couples. It is well known that the friction in piston rings amounts to as much as $50 \%$ of overall engine friction, with the work put in by the top compression ring providing the highest figure within this percentage. This is connected to the ring having to work under great temperatures (up to $200^{\circ} \mathrm{C}$ ) and in a semisuspended condition. However, the actual service life so far of the top piston rings has been much lower than the service life of other combustion engine cylinder-piston group parts. For example, the extensively used galvanic method of coating the working surfaces of piston rings with chrome reduces the wear rate by only $30 \%$ when compared to the figures exhibited by uncoated rings. This is manifestly insufficient, especially under 
great combustion pressures in cylinders which are typical for high-power combustion engines. As the compression intensity increases in combustion engines, previously used technologies which involved depositing porous chrome coatings onto the piston rings meet increasingly stringent requirements for coatings under higher temperatures and pressures to a lesser extent.

In coatings which are based on the use of deposited molybdenum and its compounds, these are often deposited on the top compression rings in the manufacture of piston rings for larger-sized engines used in haulage lorries, diesel locomotives, etc. (Figs. 4.a and 4.b). Molybdenum ensures high thermal resistance thanks to its high melting point $\left(2,620^{\circ} \mathrm{C}\right)$. Besides, by using this method of applying the coating it is possible to obtain a porous structure in the material. Motor oil can remain in microcavities on the working surfaces of the rings (Fig. 4.b), thereby preventing scouring under extreme operating conditions. Under these circumstances the coating thickness reaches between $0.5-1 \mathrm{~mm}$ and even more.

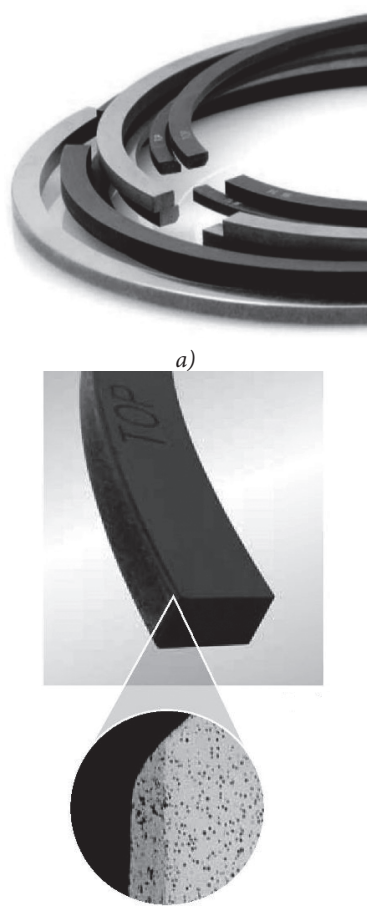

b)

Fig. 4. Design types of top compression piston ring (a) and molybdenum coating ring (b) 4. ábra Dugattyúgyürük tervezési formái (a) és molibdén bevonatos gyürü ( $b$ )

Coating to base bonding strength is doubtlessly a condition of the normal operation of rings that are coated with wearresistant coatings. As a piston ring operates in an engine, tensions linked to external forces are being applied to the rings and high temperatures arise in the adhesion contact area. Therefore the adhesive strength of the wear-resistant coating is a very important operational characteristic of piston rings in combustion engines. To a large extent, this characteristic depends upon the base surface pre-machining method. Shot blasting is used prior to the application of gas-spray coatings (in particular, the molybdenum coatings) on piston rings of largesized combustion engines. The task of ensuring the necessary surface micro-relief and shot-blasting conditions prior to the application of the wear-resistant gas-thermal coating is critical.

\section{A discussion of the research findings}

Our work considered a composite steel-molybdenum coating which was obtained from molybdenum wire and steel wire and deposited by using the gas-thermal method on the working surface of piston rings of a $210 \mathrm{~mm}$ diameter.

Prior to applying the coating, a total of twenty rings were placed on a mandrel, and a trapezoid groove was turned on the working surface of each of them. Afterwards, the rings were shot-blasted and coated with a gas-thermal coating on the same mandrel.

Adhesion strength was determined by the twist angle $\alpha$ at which the coating on finished rings sagged. The relationship between twist angle $\alpha$ and roughness parameter $R_{z}$ was determined by the use of the indirect method. At first, the relationship between $R_{z}$ and $\alpha$ and the shot change frequency $n$ was discovered, and then their mutual dependence was assessed.

Abrasive jet machining was carried out under the following conditions:

- distance between the working surface and nozzle exit: $130 \mathrm{~mm}$;

- operating air pressure: $0.4 \mathrm{MPa}$;

- number of passages: 2;

- mandrel rotation frequency: $17 \mathrm{~min}^{-1}$;

- nozzle’s angle of attack: $80^{\circ}$.

The shot was changed after the machining of 35,40 , and 43 mandrels with rings. The roughness of the ring specimens was measured on a model 201 profilograph/profilometer.

At first, we determined the relationship between the ring specimens' roughness $R_{z}$ and the shot change frequency $\mathrm{n}$ as represented in Fig. 5.a. It is evident that the roughness ensured by the newer shot is higher than it is in the older version.
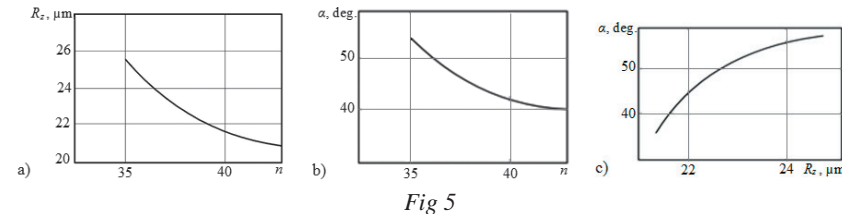

Fig 5

Fig. 5. Relationship between roughness $R z$ (a) and twisting angle $\alpha(b)$ and shot changing frequency and between and twisting angle $\alpha$ and surface roughnes $R_{z}$ after abrasive jet machining (c)

5. ábra Összefüggés a felületi érdesség Rz (a) és az elfordulási szög $\alpha$ (b) között valamint a lövési frekvencia és az elfordulási szög $\alpha$ és a felületi érdesség $R_{z}$ között abrazív vízsugaras megmunkálást követöen (c)

The results of tests aimed at determining the twist angle a at which the coating would delaminate depending on the shot change frequency are shown in Fig. 5.b. The twist angle varied from $57^{\circ}$ at $n=35$ to $39^{\circ}$ at $n=43$.

A study of the results presented in Figs. 5. $a$ and $5 . b$ means that the relationship between twist angle $\alpha$ and roughness $R_{z}$ (Fig. 5.c) can be obtained. It can be seen that, within the roughness variation range being studied, the aforementioned relationship is approximated as a virtually linear one, i.e. adhesion strength increases as surface roughness increases.

Therefore, when taking into account the fact that as operational experience shows, the piston rings operate normally when the coating separates at twist angles exceeding $35^{\circ}$, so that one can conclude that shot must be changed after 
machining a maximum of forty mandrels. The minimum roughness in this case would be limited to $R_{z} \geq 22 \mu \mathrm{m}$.

In the second series of tests which were aimed at ensuring the required surface roughness following abrasive jet machining, various conditions for such machining were studied and their relationship with roughness parameters were uncovered. In each set of experiments, one of the machining parameters varied: the distance between the working surface and the nozzle exit, the number of passages, or the operational air pressure, while two other characteristics remained unchanged.

In the first set of experiments, the distance between the working surface and the nozzle exit varied $(70 \mathrm{~mm}, 90 \mathrm{~mm}$, $110 \mathrm{~mm}, 130 \mathrm{~mm}$, and $150 \mathrm{~mm}$ ). Machining was carried out in two passes at a $0.4 \mathrm{MPa}$ operational air pressure. Fig. 6.a demonstrates that $110 \mathrm{~mm}$ should be used as the optimum distance between the working surface and the nozzle exit both for the new shot method and for shots after machining a total of forty mandrels.

In the second set of experiments, the number of passages varied $(k=1,2,3)$. The distance between the working surface and the nozzle exit was set at $110 \mathrm{~mm}$ and the operational air pressure was at $0.4 \mathrm{MPa}$. As illustrated in Fig. 6.b, $k=2$ should be considered as being the optimum value.

In the third series, the operation air pressure varied $(P=$ $0.35 \mathrm{MPa}, 0.40 \mathrm{MPa}$, and $0.45 \mathrm{MPa}$ ). The number of passes was set at two and the distance between the working surface and the nozzle exit was $110 \mathrm{~mm} . P=0.4 \mathrm{MPa}$ should be considered as being the optimum figure with regard to obtaining the necessary roughness (Fig. 6.c).
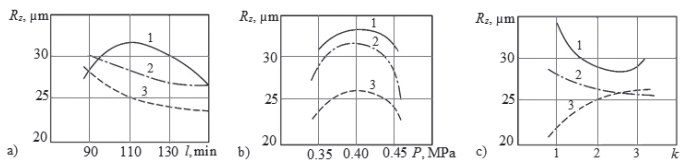

Fig. 6. Relationship between surface roughness and abrasive jet machining conditions: distance between Workpiece and Nozzle Exit (a), number of passages (b), operation air pressure (c): 1 - new shot; 2 - shot after machining 20 mandrels; 3 - shot after machining 40 mandrels

6. ábra Összefüggés a felületi érdesség és az abraziv vízsugaras megmunkálás körülményei között: távolság a munkadarab és a fúvóka között (a), ismétlésszám (b), működési levegönyomás (c): 1 - első lövés; 2 - lövés 20 tüske megmunkálás után; 3 - lövés 40 tüske megmunkálás után

It can be seen that our studies resulted in the discovery of the relationship between the adhesion strength of the gas-thermal wear-resistant coating on the piston rings and the roughness of the working surface following abrasive jet machining and establishing machining conditions which ensure the optimum levels of roughness: operational air pressure - $0.4 \mathrm{MPa}$; number of passages - two; distance between the working surface and the nozzle exit $-110 \mathrm{~mm}$. The shot must be changed following the abrasive jet machining of a maximum of forty mandrels with rings.

\section{Conclusions}

1. Surface roughness obtained as a result of abrasive jet machining exerts a considerable level of impact upon the adhesion strength of coating as obtained by gas-thermal and plasma flame spraying.

2. Spray coatings based on molybdenum and its compound are extensively used in the manufacture of piston rings for large-size combustion engines. Coating adhesion to the base surface is closely associated with obtaining the necessary levels of roughness and abrasive jet machining conditions.

3. We have proposed the use of abrasive jet machining conditions (operation air pressure: $0.4 \mathrm{MPa}$, distance between working surface and nozzle exit $-110 \mathrm{~mm}$, number of passages - two, shot change needed after machining forty mandrels), which ensure the required roughness levels in the piston ring's working surface $(\mathrm{Rz} \geq 22 \mu \mathrm{m})$ prior to applying the coating.

\section{References}

[1] Drozdov, Y. N. - Yudin, E. G. - Belov, A. I. (2010): Applied tribology (friction, wear and lubrication) Eco-Press. Moscow. 604 pp.

[2] Suslov, A. G. - Fedorov, B. N. - Gorlenko, O. A. (2006): Technological support and enhance the operational properties of parts and their connections. Mechanical Engineering, Moscow, 448 pp.

[3] Maksarov, V. - Krasnyy, V. (2017): The formation of surface roughness of piston rings for the purpose of improving the adhesion of wear-resistant coatings. Key Engineering Materials, Vol. 736, pp. 73-78. https://doi.org/10.4028/www.scientific.net/KEM.736.73

[4] Krasnyy, V. - Maksarov, V. - J. Olt. (2016): Increase of wear and fretting resistance of mining machinery parts with regular roughness patterns. Annals of DAAAM and Proceedings of the International DAAAM Symposium. Vol. 17, Issue 1, pp. 151-156. https://doi.org/10.2507/27th.daaam.proceedings.023

[5] Holmberg, K. - Matthews, A. (2009): Coatings Tribology - Properties, Mechanisms, Techniques and Applications in Surface Engineering, Tribology and Interface Engineering Series 56, Elsevier, Amsterdam, $560 \mathrm{pp}$.

[6] Musil, J. (2000): Hard and super hard nanocomposite coatings. Surface and Coatings Technology. Vol. 125, Issue 13, pp. 322-330. https://doi.org/10.1016/S0257-8972(99)00586-1

[7] Agarwala, R.C. - Agarwala, V. (2003): Electroless alloy/composite coatings. A review. Sadhana - Academy Proceedings in Engineering Sciences, Vol. 28, Issue 3-4, pp. 475-493.

[8] Kamo, L. - Saad, P. - Saad, D. - Bryzik, W. - Mekari, M. H. (2007): Diesel Engine Cylinder Bore Coating for Extreme Operating Conditions, SAE Technical Paper, 2007-01-1439, https://doi.org/10.4271/2007-01-1439

[9] Shaffer, S. J. - Rogers, M. J. (2007): Tribological performance of various coatings in unlubricated sliding for use in small arms action components - A case study. Wear, Vol. 263, Issue 7-12, pp. 1281-1290. https://doi.org/10.1016/j.wear.2007.01.115

[10] Donnet, C. - Erdemir, A. (2003): Historical developments and new trends in tribological and solid lubricant coatings. Saint-Etienne, France: Elsevier B.V.

[11] Loomis, W. (1985): New Directions in Lubrication, Materials, Wear, and Surface Interactions. Park Ridge, New Jersey: Noyes Publications.

[12] Sigmund, P. (1987): Mechanisms and theory of physical sputtering by particle impact. Nuclear Instruments and Methods in Physics Research, Section B, Beam Interactions with Materials and Atoms 27: 1. https://doi.org/10.1016/0168-583X(87)90004

[13] Krasnyy, V. A. - Maksarov, V. V. - Olt, J. (2015): The use of polymer composite materials in the friction nodes downhole oil pumps. Notes of the Mining Institute. 2015. Vol. 211, pp. 71-79.

[14] Krasnyy, V. - Maksarov, V. - Olt, J. (2016): Improving fretting resistance of heavily loaded friction machine parts using a modified polymer composition. Agronomy Research, Vol. 14, Special Issue 1, pp. 1023-1033.

\section{Ref.:}

Olt, Jüri - Maksarov, Viacheslav V. - Krasnyy, Victor A.: Pre-surface preparation features when applying wear resistant composite sprayed coatings

Építőanyag - Journal of Silicate Based and Composite Materials, Vol. 70, No. 2 (2018), 34-37. p.

https://doi.org/10.14382/epitoanyag-jsbcm.2018.7 